\title{
SUISTAINABLE TOURISM DESWITA BERKEMBANG MENJADI DESWITA MAJU DI DESA WISATA SUMBERBULU
}

\author{
Erna Wigati ${ }^{1}$, dan Wahyu Ari Indriastuti ${ }^{2}$ \\ 1,2 Akademi Pariwisata Mandala Bhakti, Surakarta, Indonesia, ernawigati16@gmail.com
}

\begin{abstract}
ABSTRAK
Histori Artikel

Submitted:

6 Agustus 2021

Reviewed:

8 September 2021

Accepted:

15 Oktober 2021

Published:

15 November 2021

Artikel ini bertujuan untuk mengetahui desa wisata sumberbulu dalam berkontribusi terhadap kesejahteraan sosial memiliki jaringan ekonomi lokal dan regional. Metode yang digunakan adalah menggunakan metode kualitatif diskriptif, dengan analisis data dilakukan secara induktif. Adapun untuk mengetahui suistainable tourism desa wisata berkembang menjadi maju di desa wisata sumberbulu karanganyar. Hasil dari penelitian ini Desa wisata sumberbulu dalam memberikan kontribusi terhadap kesejahteraan ekonomi dan sosial secara tidak langsung sudah nampak dengan adanya banyak pembeli yang membeli tanaman hias waktu berkunjung ke desawisata sumberbulu. Pemesanan makanan kecil yang sudah diproduksi oleh warga masyarakat dari pembentukan team kecil kuliner dari beberapa rumah penduduk. Kualitas untuk pramuwisata di desa wisata sumberbulu belum begitu terlihat karena semua masih menyatu dengan pokdarwis. Kualitas akomodasi (homestay) di desa wisata sumberbulu semakin hari semakin baik karena selalu dicek oleh tim pengelola homestay dari koordinator homestay yang sudah dibentuk dari pokdarwis.
\end{abstract}

Kata Kunci: Suistainable, Tourism, Deswita Berkembang, Deswita Maju

\section{SUISTAINABLE TOURISM TOURIST VILLAGE GROW INTO ADVANCED DESWITIES IN SUMBERBULU TOURISM VILLAGE}

\section{ABSTRACT}

This study aims to determine the quality of Sumberbulu tourism village in contributing to social welfare by having a local and regional economic network. Methods used in this reseach is to use descriptive qualitative method, with data analysis done inductively. The aim is to find out sustainable tourism village to develop into the tourism village of Sumberbulu Karanganyar. The result this study, Sumberbulu tourism village, in contributing to economic and social welfare has inderectly been seen by the presence of many buyers who buy ornamental plants when visiting Sumberbulu Village and orrdering snacks that have been produced by community members from the formation of small culinary teams from several residens houses. The quality of the tour guides in the Sumberbulu tourist village is not yet visible because everything is still one with pokdarwis. The quality of accomodation (homestay) in the tourist village of Sumberbulu is geting better and better because it is always checked by the homestay management team from the homestay coordinator who has been formed from pokdarwis.

Keywords: Suistainable, Tourism, a thriving tourist village, advanced tourist village

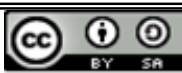

http://jurnal.ampta.ac.id/index.php/MWS

Doi: $10.36275 / \mathrm{mws}$ 



\section{PENDAHULUAN}

Potensi wisata yang luar biasa yang dimiliki oleh negara Indonesia seharusnya dapat menjadikan andalan untuk mengangkat taraf hidup masyarakat. Sektor pariwisata dapat menjadi sektor penopang pemasukan negara di bidang non migas. Di era yang semakin maju dan berkembang ini kebutuhan orang dalam berwisata sangatlah tinggi. Masyarakat memiliki banyak cara yang bisa dilakukan untuk mengangkat potensi wisata di suatu daerah. Setiap daerah memiliki potensi yang bisa dikembangkan menjadi keunggulan yang dimiliki sebagai karakteristik alam maupun sosial kultural dan aspek lainnya.

Desa memiliki potensi sebagai destinasi wisata yang berbasis komunitas dan berlandaskan pada kearifan lokal kultural masyarakat dan dapat sebagai pendorong peningkatan ekonomi yang berprinsip gotong royong dan berkelanjutan. Hal ini sesuai dengan konsep membangun dari pinggiran atau dari desa untuk mensejahterakan masyarakat Indonesia dengan menggali potensi lokal dan pemberdayaan masyarakat yang dicanangkan oleh pemerintah sebagai program prioritas.

Desa wisata adalah komunitas yang terbentuk dari masyarakat desa yang terdiri dari para penduduk suatu daerah yang bisa saling berinteraksi secara langsung dibawah pengelolaan dan memiliki kepedulian kesadaran dalam berperan bersama sesuai kemampuan masing masing dalam menggalakkan sapta pesona dan sadar wisata sehingga meningkatkan taraf hidup warga sekitarnya dan kesejahteraan masyarakat menjadi meningkat.

Desa wisata sumberbulu adalah desa wisata yang dikelola oleh pokdarwis dan warga sekitarnya mulai bulan september 2018 dan menjadi Desa Dampingan Akademi Pariwisata Mandala Bhakti Surakarta pada tahun 2019. Dengan adanya pendampingan membawa pengaruh yang luar biasa karena desa tersebut dari sistem pengelolaan yang hanya ala kadarnya menjadi desa wisata yang pokdarwisnya dan desa wisata tersebut memiliki legalitas berupa $\mathrm{Sk}$ bupati karanganyar.

Desa wisata sumberbulu ini yang ditonjolkan adalah kearifan lokal desa tersebut. Dari penelitian awal yang berjudul Peran pemberdayaan masyarakat dalam mengembangkan desa wisata di desa sumberbulu mojogedang karanganyar. Peneliti ingin melanjutkan dengan penelitian suistainable tourism desa wisata berkembang menjadi desa wisata maju di Desa Sumberbulu Mojogedang Karanganyar. Hal ini untuk keberlanjutan desa wisata sumberbulu sendiri dalam pengelolaannya dan perkembangannya bagaimana setelah menjadi berkembang apakah desa tersebut bisa menjadi desa wisata yang maju.

\section{LITERATURE REVIEW}

Suistainable tourism development is tourism development that meet the needs of the present without compromising the ability of future generations to meet their own without compromising the ability of future generations to meet their own needs. (Weaver: 2000). (Sugiama: 2016)

Pariwisata berkelanjutan adalah kepariwisataan yang dikembangkan dengan memperhatikan kelestarian lingkungan alam dan budaya masyarakat setempat, sehingga dapat diwariskan untuk generasi mendatang. Lane dalam sharply, (2000: 8) pariwisata berkelanjutan adalah hubungan triangulasi yang seimbang antara tujuan wisata (host areas) dengan habitat dan manusianya, perbuatan paket liburan (wisata), dan industri pariwisata dimana tidak ada satupun stakeholder dapat merusak keseimbangan. WTO (2011), Sustainable tourism that takes full account of its current and future economic, social and environmental impacts, addressing the needs of visitors, the industry, the environment and host communitis. (Sharpley: 2000) pariwisata berkelanjutan terarah pada penggunaan sumber daya alam dan penggunaan sumber daya manusia untuk jangka waktu tertentu. 
Menurut (Sugiama: 2014) terdapat 7 prinsip yang dapat memandu pengembangan pariwisata berkelanjutan yaitu: 1) Lingkungan adalah nilai intrinsik (instrinsic Value) yang mana nilai tersebut menjadi kekayaan kepariwisataan. Kesadaran pemeliharaan lingkungan yang harus dijadikan sebagai amanat untuk mewariskannya kepada generasi penerus. 2) Pariwisata harus dikembangkan sebagai aktivitas positif yang potensial menciptakan benefit bagi komunitas/masyarakat setempat dan bagi para wisatawan bersangkutan. 3) Pengembangan kepariwisataan dengan lingkungan harus dikelola dengan mutlak memperhatikan pemeliharaan lingkungan untuk jangka panjang, menghindari kerusakan sumber daya dan sangat memperdulikan kelestarian alam untuk masa yang akan datang. 4) Aktifitas kepariwisataan harus respek pada skala, kondisi alam, dan karakter tempat dimana pariwisata tersebut dikembangkan. 5) Di beberapa lokasi tertentu, penting memperhatikan harmonisasi antara kebutuhan pengunjung dengan tempat wisata dan dengan penduduk setempat. 6) Menghindari dinamika pengembangan kepariwisataan yang menyebabkan biaya perbaikan kerusakan lingkungan lebih besar daripada keuntungan yang diperoleh dari kepariwisataan bersangkutan. 7) Semua pihak yang terkait dengan pengembangan kepariwisataan (industri, penduduk setempat, pemerintah, dan wisatawan) harus bersatu padu berupaya menerapkan prinsip-prinsip pemeliharaan lingkungan.

Menurut (Sugiama: 2014) suistainable tourism dapat dikembangkan di setiap daerah tujuan wisata terutama di destinasi yang memiliki alam dan budaya yang masih utuh. Sebagai dasar pemikiran pengembangan pariwisata berkelanjutan diterapkan model pengembangan suistainable tourism seperti gambar dibawah ini:

Visitor

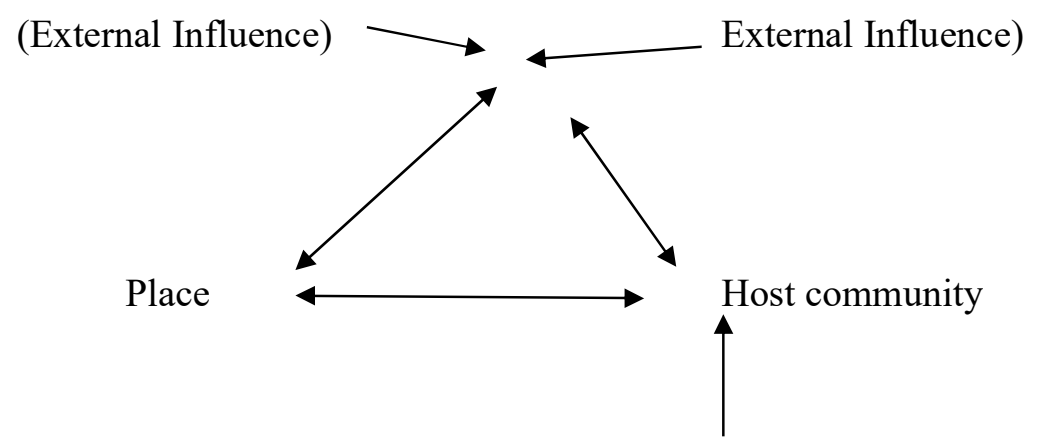

External Influence)

Gambar 2. 1 Model Suistainable Turism

Sumber: A. Gima, 2014

Menurut (Sugiama: 2016) isu kepariwistaan berkelanjutan atau suistainable tourism memiliki beberapa slogan yaitu green speak, go green dan green tourism. Suistainable tourism merupakan aspek yang didalammya ada 3 P yaitu People,Planet, dan Prosperity. Aspek people menjadi dasar utama dimana penyedia jasa harus memperhatikan keinginan dan kebutuhan wisatawan.
Aspek planet berarti bagaimana cara/upaya dalam merawat dan menjaga obyek dan destinasi wisata, dan aspek prosperity terkait dengan nilai ekonomis obyek dan destinasi wisata dan dampaknya bagi masyarakat sekitar dimasa mendatang. Pembanguna pariwisata berkelanjutan ditandai dengan 4 kondisi menurut (Yaman dan Mohd: 2004) yaitu: 1) Anggota masyarakat harus 
berpartisipasi dalam proses perencanaan dan pembangunan pariwisata. 2) Pendidikan bagi tuan rumah, pelaku industri dan pengunjung/wisatawan. 3) Kualitas kehidupan liar, penggunaan energi dan iklim mikro harus dimengerti dan di dukung. 4) Investasi pada bentuk bentuk transportasi alternative.

Indikator yang dikembangkan RI tentang pembangunan pariwisata berkelanjutan (Agenda 21 sektoral, 2000) adalah 1) Kesadaran bertanggungjawab terhadap lingkungan, bahwa strategi pembangunan pariwisata berkelanjutan harus menempatkan pariwisata sebagai green industry (industri yang ramah lingkungan) yang menjadi tanggung jawab pemerintah, industri pariwisata, masyarakat dan wisatawan. 2) Peningkatan peran pemerintah daerah dalam pembangunan pariwisata.

Kemantaban/keberdayaan industri pariwisata yaitu mampu menciptakan produk pariwisata yang bisa bersaing secara internasional dan bisa mensejahterakan masyarakat di tempat tujuan wisata. 4) Kemitraan dan partisipasi masyarakat dalam pembangunan pariwisata yang bertujuan menghapus dan meminimalisir perbedaan tingkat kesejahteraan wisatawan dan masyarakat di daerah tujuan wisata untuk menghindari konflik dan dominasi satu sama lain yang didukung dengan memberi perhatian / pengembangan usaha skala kecil oleh masyarakat lokal.

(Arronsson: 2000) menginterprestasikan pariwisata berkelanjutan yaitu: 1) Mampu mengatasi sampah lingkungan serta memiliki perspektif ekologi. 2) Menunjukkan keterpihakannya pada pembangunan berskala kecil dan berbasis masyarakat lokal/ setempat. 3) Menempatkan daerah tujuan wisata sebagai penerima manfaat dari pariwisata, untuk mencapainya tidak harus mengeploitasi daerah setempat. 4) Menekankan keberlanjutan budaya yang menekankan pada upaya upaya membangun dan mempertahankan bangunan tradisional dan peninggalan budaya di daerah pariwisata.

Menurut Pariwisata Inti Rakyat (PIR) dalam Hadiwijoyo, (2012) desa wisata adalah suatu daerah wisata yang menyajikan keseluruhan suasana yang mencerminkan keaslian perdesaan baik dari sisi kehidupan sosial, ekonomi, budaya, keseharian, adat istiadat, memiliki arsitektur dan tata ruang yang khas dan unik, atau kegiatan perekonomian yang unik dan menarik serta memiliki potensi untuk dikembangkannya komponen kepariwisataan seperti akomodasi, makanan, minuman dan atraksi lainnya.

Kementrian Kebudayaan dan Pariwisata (2011) menyatakan Suatu desa wisata memiliki daya tarik yang khas (dapat berupa keunikan fisik lingkungan alam perdesaan, maupun kehidupan sosial budaya masyarakatnya) yang dikemas secara alami dan menarik sehingga daya tarik perdesaan dapat menggerakkan kunjungan wisatawan ke desa tersebut disebut Desa wisata. Menurut Soetarso Priasukmana (2001), Desa wisata merupakan suatu obyek wisata yang memiliki potensi seni dan budaya unggulan di suatu wilayah perdesaan yang berada di pemerintah daerah.

Desa wisata menurut wiendu (1993〉) adalah suatu bentuk integrasi antara atraksi, akomodasi dan fasilitas pendukung yang disajikan dalam suatu struktur kehidupan masyarakat yang menyatu dengan tata cara dan tradisi yang berlaku. Menurut darsono (2005) Desa wisata adalah suatu wilayah pedesaan yang menawarkan keaslian baik dari segi sosial budaya, adat- istiadat, keseharian, arsitektur tradisional, struktur tata ruang desa yang disajikan dalam suatu suatu bentuk integrasi komponen pariwisata antara lain seperti atraksi, akomodasi dan fasilitas pendukung. Menurut Peneliti desa wisata adalah desa yang memiliki atraksi, akomodasi dan pendukung fasilitas lainnya yang menarik wisatawan untuk berkunjung dan menikmati potensi yang ada di desa tersebut. 
Tabel 1: Kriteria Desa Wisata Berkembang :

Kepemilikan dan kepengurusan oleh masyarakat

Kontribusi terhadap kesejahteraan sosial

Kontribusi untuk menjaga dan meningkatkan kualitas lingkungan

Mendorong terjadinya partisipasi interaktif antara masyarakat lokal dan pengunjung (wisatawan).

Kualitas makanan dan minuman

Kualitas akomodasi (homestay)

Kinerja friendly Tour Operator
Terdapat pengelolaan yang efektif dan transparan, Legalitas lembaga atau kelompok desa, Memiliki kemitraan yang efektif.

Menjaga Martabat Manusia, Pembagian biaya dan keuntungan yang adil, Melestarikan dan memperkaya tradisi dan budaya setempat.

Melestarikan Sumber Daya Alam, Aktivitas konservasi untuk meningkatkan kualitas lingkungan.

Terdapat interaksi antara tamu dan masyarakat lokal, Keberlanjutan Produk produk pariwisata berbasis masyarakat.

Kualitas Pelayanan Makanan dan minuman, Memastikan kualitas perjalanan wisata

Kualitas layanan akomodasi

Komitmen pada nilai-nilai ideal desa wisata, Kontribusi terhadap perlindungan masyarakat dan alam, Mempromosikan indahnya penemuan, pengetahuan dan penghargaan,Mempromosikan pengalaman yang memuaskan dan aman bagi wisatawan dan masyarakat.

Tabel 2: Kriteria desa wisata Maju

Kepemilikan dan kepengurusan oleh masyarakat

Kontribusi terhadap kesejahteraan sosial

Kontribusi untuk menjaga dan meningkatkan kualitas lingkungan

Mendorong terjadinya partisipasi interaktif antara masyarakat lokal dan pengunjung (wisatawan).

Jasa Wisatawan dan pramuwisata yang berkualitas Kualitas makanan dan minuman

Kualitas akomodasi (homestay)

Kinerja friendly Tour Operator
Terdapat pengelolaan yang efektif dan transparan, Legalitas lembaga atau kelompok desa, Memiliki kemitraan yang efektif

Menjaga Martabat Manusia, Pembagian biaya dan keuntungan yang adil, Memiliki jaringan ke ekonomi lokal dan regional, Melestarikan dan memperkaya tradisi dan budaya setempat.

Melestarikan Sumber Daya Alam, Aktivitas konservasi untuk meningkatkan kualitas lingkungan

Terdapat interaksi antara tamu dan masyarakat lokal, Keberlanjutan Produk produk pariwisata berbasis masyarakat.

Kualitas keahlian pramuwisata desa wisata.

Kualitas Pelayanan Makanan dan minuman, Memastikan kualitas perjalanan wisata

Kualitas layanan akomodasi, Memastikan pengelolaan akomodasi yang berkualitas

Komitmen pada nilai-nilai ideal desa wisata, Kontribusi terhadap perlindungan masyarakat dan alam, Dukungan terhadap ekonomi lokal, Mempromosikan indahnya penemuan, pengetahuan dan penghargaan, Mempromosikan pengalaman yang memuaskan dan aman bagi wisatawan dan masyarakat.

\section{METODE}

kegiatan ini dilaksanakan di Desa Wisata Sumberbulu, Dusun Sumberbulu, Desa Pendem, Kecamatan Mojogedang, Kabupaten Karanganyar, Jawa Tengah yang menggunakan metode kualitatif (deskriptif) tujuannya untuk mengetahui suistainable tourism desa wisata berkembang menjadi maju di Desa Wisata Sumberbulu Karanganyar.
Sumber data yang digunakan adalah data primer berupa hasil observasi dan wawancara dengan narasumber dari Tokoh masyarakat Desa Sumberbulu, Pengurus Pokdarwis, Pemilik Homestay. Data sekunder dalam penelitian ini adalah buku-buku referensi, brosur, dan catatan-catatan yang berkaitan dengan subjek penelitian.

Metode pengumpulan data dengan observasi yaitu peneliti langsung terjun ke desa wisata 
sumberbulu melakukan pengamatan tentang suistainable tourism desa berkembang menjadi desa maju di desa wisata sumberbulu, dan wawancara dengan Tokoh masyarakat Desa Sumberbulu, Pengurus Pokdarwis, Pemilik Homestay.

Metode analisis dalam penelitian ini menggunakan model analisis interaktif terdiri dari tiga alur kegiatan yang terjadi secara bersamaan, yaitu reduksi data, penyajian data dan penarikan kesimpulan atau verifikasi, menurut Miles (1992: 16).

\section{HASIL DAN PEMBAHASAN}

Kontribusi Desa Wisata Sumberbulu terhadap Kesejahteraan Sosial

Desa wisata sumberbulu dalam memberikan kontribusi terhadap kesejahteraan ekonomi dan sosial secara tidak langsung sudah nampak dengan adanya pembeli yang membeli tanaman hias waktu berkunjung ke desawisata sumberbulu. Pemesanan snack/makanan kecil yang sudah diproduksi oleh warga masyarakat dari pembentukan team kecil kuliner dari beberapa rumah penduduk. Hal ini berkontribusi terhadap kesejahteraan sosial bahwa masyarakat bisa mendapatkan biaya tambahan, pendidikan orang tua lebih banyak mengarahkan anakanaknya ke hal-hal yang positif, dengan adanya sanggar kesenian menjadikan peluang warga untuk mengembangkan bakat seninya dan itu bisa digunakan dalam penyambutan tamu atau pengunjung, Masyarakat ada kesadaran untuk pendapatan wisata, mereka menanam bunga dari samping rumah yang terjual dari tamu-tamu yang datang, konsumsi dari masyarakat sendiri jadi kesadaran masyarakat sudah ada perkembangan. Jaringan ekonomi lokal lebih ke pertanian, stock beras merah berkurang mengambil ke desa sebelah, kerajianan bambu bekerja sama dengan desa sebelah, gethuk lindri ambil dari desa sebelah, ada tamu yang ingin keliling tapi tidak mau jalan kaki akhirnya pakai sepur kelinci dan itu sudah ada kerjasama dengan desa sebelah. Sehingga untuk ekonomi regionalnya belum ada pendapatan yang dibilang banyak tapi semua masih di pengembangan desa wisata dan lokal wisata. Adapun untuk daftar pengunjung yang datang di tahun 2018-2019 bisa dilihat dari tabel berikut:

Tabel 3: Jumlah Pengunjung Desa Wisata Sumberbulu tahun 2018-2019

\begin{tabular}{lcc}
\hline \multicolumn{1}{c}{ Bulan } & Jumlah Pengunjung & $\%$ \\
\hline November 2018 & 20 & 0,2 \\
Desember 2018 & 30 & 0,3 \\
Februari 2019 & 35 & 0,35 \\
Maret 2019 & 75 & 0,75 \\
Mei 2019 & 76 & 0,76 \\
Juni 2019 & 120 & 1,2 \\
september 2019 & 150 & 1,5 \\
Oktober 2019 & 170 & 1,7 \\
Desember 2019 & 179 & 1,79 \\
\hline
\end{tabular}




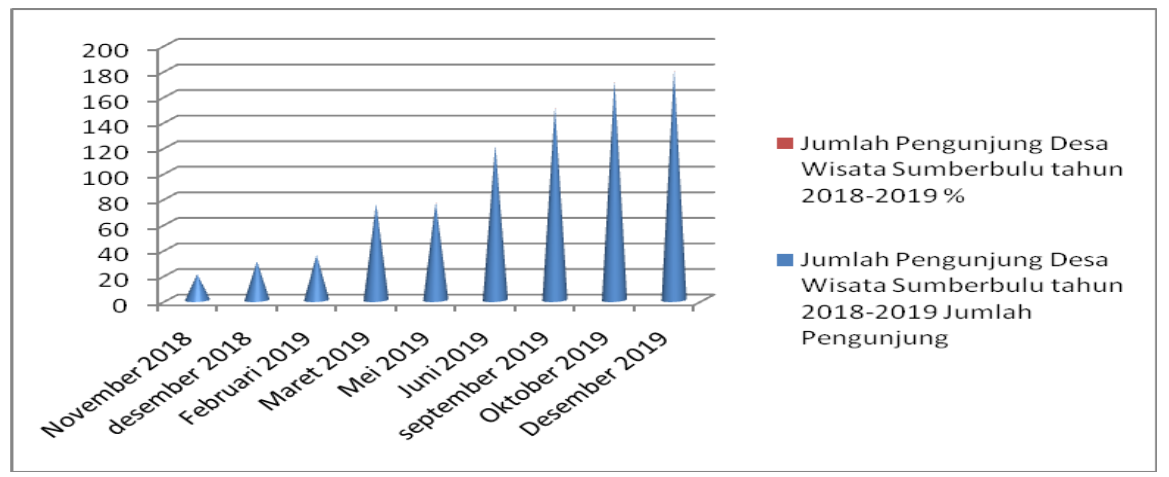

Grafik 1: Jumlah Pengunjung tahun 2018-2019

Dari tabel dan grafik diatas bisa dilihat bahwa dari bulan November 2018 sampai Desember 2019 tiap bulan terjadi pertambahan jumlah pengunjung yang datang berkunjung ke desa wisata sumberbulu dan ini menjadi nilai tambah untuk kesejahteraan masyarakat di desa wisata tersebut.

Tabel 4: Jumlah Pengunjung Desa Wisata Sumberbulu tahun 2020

\begin{tabular}{lcc}
\hline Bulan & Jumlah Pengunjung & $\%$ \\
\hline Januari 2020 & 177 & 1,77 \\
Februari 2020 & 180 & 1,8 \\
Maret 2020 & 0 & 0 \\
April 2020 & 0 & 0 \\
Mei 2019 & 0 & 0 \\
Juni 2019 & 70 & 0,7 \\
\hline
\end{tabular}

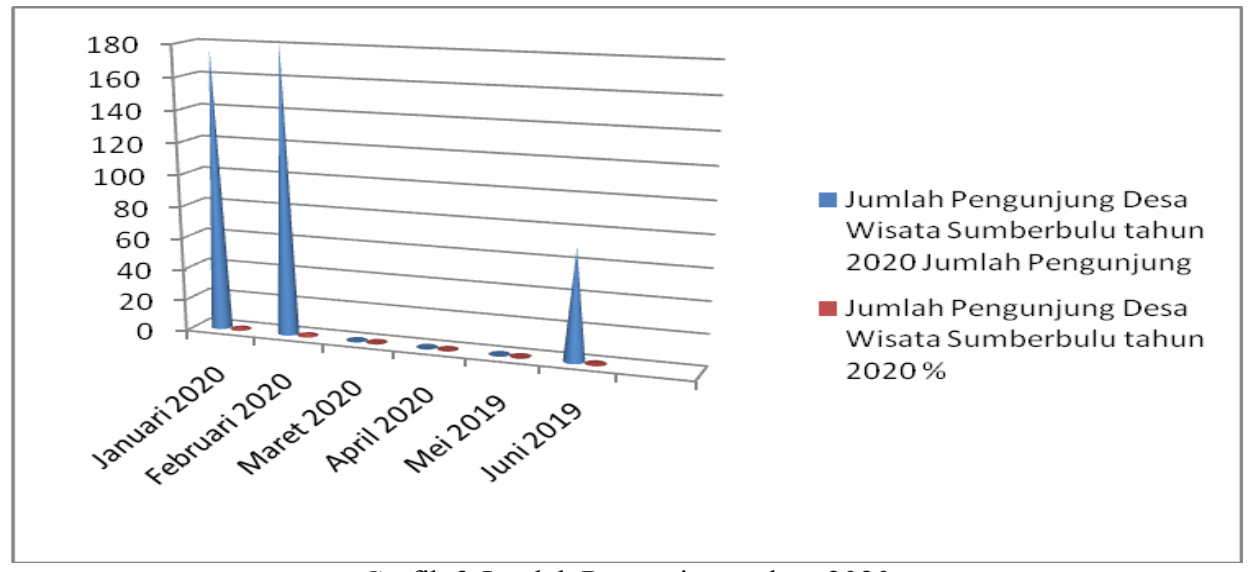

Grafik 2 Jumlah Pengunjung tahun 2020

Dari tabel dan grafik diatas bisa dilihat bahwa untuk tahun 2020 di awal bulan desa wisata sumberbulu ada kenaikan pengunjung di 2 bulan pertama di bulan januari 2020 dan februari 2020 tapi di bulan Maret-Mei tidak ada pengunjung sama sekali karena desa wisata sumberbulu mengalami dampak dari pandemi covid-19 yang akhirnya desa wisata tersebut harus di tutup sesuai aturan dari pemerintah untuk tidak membuka tempat 
wisata selama masa pandemi covid 19 sampai ada pengumuman dari gugus sehat kalau kondisi sudah normal kembali sehingga selama 3 bulan tidak ada kegiatan kecuali para warga masayarakat desa sumberbulu tetap bertani di sawah. Hal ini memang berdampak terhadap ekonomi dan sosial untuk masyarakat desa wisata sumberbulu.

Kualitas Keahlian Pramuwisata Desa Wisata dalam Jasa Perjalanan Wisata dan Pramuwisata yang Berkualitas untuk Desa Sumberbulu pada Tahun 2020.

Kualitas untuk pramuwisata di desa wisata sumberbulu belum begitu terlihat karena semua masih menyatu dengan pokdarwis. Kandidat para pramuwisata yang seharusnya di siapkan dari para pemuda belum begitu maksimal karena mereka masih kurang percaya diri dalam menyambut tamu atau pengunjung dan dalam memberikan pelayanan berupa telling stories untuk atraksi yang ada di desa wisata tersebut. Saat ini yang sudah berjalan banyak pemuda yang pulang ke desa wisata sumberbulu yaitu kampung halamannya dari merantau ke daerah lain atau ke negara lain dengan tujuan pulang ke kampung halaman untuk membangun desanya agar lebih banyak wisatawannya. Dan saat ini mereka sudah belajar membuat event dan memasarkan untuk desa wisata sumberbulu. Adapun media yang ada sekarang sudah ada adalah facebook: Deswita-Sumberbulu, Instagram: Sumberbulu_Village, Email: sumberbuluvillage@gmail.com, dan youtobe: Desa Wisata Sumberbulu. Berikut aktivitas pemuda pemudi pramuwisata yang sedang berkumpul di kesekretariatan dalam rangka berlatih membuat event dan kegiatan untuk penyambutan tamu atau pengunjung yang akan berkunjung di desa wisata sumberbulu.

\section{Kualitas Homestay dalam Pengelolaan di Desa Sumberbulu pada Tahun 2020.}

Kualitas akomodasi (homestay) di desa wisata sumberbulu semakin hari semakin baik karena selalu dicek oleh tim pengelola homestay dari koordinator homestay yang sudah dibentuk dari pokdarwis. Dari mulai pengecekan dan tingkat kesiapan homestay sudah sangat layak dan bagus sesuai kriteria yang sudah ditentukan dari awal. Koordinator homestay juga sangat rajin dalam memberikan arahan kepada masyarakat pemilik homestay dalam update informasi untuk kenyamanan dan keselamatan para pengunjung yang datang berkunjung dan memilih paket live in di homestay. Pengelolaan akomodasi yang saat ini sudah mulai nampak perkembangan dan keberlanjutannya adalah adanya penambahan yaitu berupa pembangunan pendopo pertemuan, pembuatan wastafel, dan pengaspalan jalan desa.

\section{Kinerja Friendly Tour Operator di Desa Wisata Sumberbulu Tahun 2020.}

Kinerja friendly tour operator di desa wisata sumberbulu belum begitu maksimal karena masih dipegang dan dihandel langsung oleh manager desa wisata sumberbulu. Sedangkan Standart operator prosedur untuk tour operatornya juga belum dibuat dan ditetapkan. Dari pembahasan diatas ditarik kesimpulan bahwa suistainable tourism desa wisata sumberbulu dari desa wisata berkembang untuk menjadi desa wisata maju belum begitu maksimal dan masih banyak yang harus dibenahi dan disiapkan.

Kesimpulan artikel ini adalah (1) Kontribusi terhadap keseahteraan masyarakat sudah terdapat pembagian yang adil dalam hal pembagian biaya dan keuntungan. Masyarakat saling menjaga martabat manusia dan warga sudah melestarikan serta memperkaya tradisi dan budaya setempat dengan adanya kesenian reog, jatilan dan kotek lesung yang dibawakan oleh ibu-ibu warga desa wisata sumberbulu. (2) Kualitas dari homestay sudah memadai dilihat dari kelayakan homestay, kualitas pelayanan makanan dan minuman yang diberikan dan kepuasan tamu yang menginap dibuktikan dengan datangnya tamu yang sama berulang kali dan menginap untuk mengambil paket live in. (3) Kualitas keahlian pramuwisata desa wisata sumberbulu yang masih harus dibenahi untuk menjadi desa wisata yang maju. (4) Kinerja friendly tour operator belum bisa berkomitmen pada nilai-nilai ideal desa wisata sumberbulu karena belum 
ada orang yang tetap atau Sumber daya manusia (SDM) yang handal untuk mengurusinya sehingga kontribusi terhadap perlindungan masyarakat dan alam, dalam mempromosikan indahnya penemuan, pengetahuan dan penghargaan serta pengalaman yang memuaskan dan aman bagi wisatawan dan masyarakat belum begitu maksimal sehingga dukungan terhadap ekonomi lokal belum nampak.

\section{SIMPULAN}

Suistainable tourism desa wisata sumberbulu mojogedang karanganyar dari desa wisata berkembang untuk menjadi maju masih ada beberapa yang harus disiapkan dan dibenahi. Desa wisata sumberbulu dalam berkontribusi terhadap kesejahteraan sosial sudah sangat tinggi tapi masih tingkat lokal dan belum bisa kearah regional karena kondisi Sumber daya manusia yang masih perlu pendampingan untuk diberikan pelatihan.

Kualitas keahlian pramuwisata desa wisata dalam jasa perjalanan wisata dan pramuwisata belum maksimal karena masih kurangnya rasa percaya diri bagi remaja desa wisata sumberbulu dalam melayani pengunjung yang datang. $\mathrm{K}$

ualitas homestay sangat memadai, nyaman dan aman karena koordinator pengelolaannya sudah dikelola dengan baik dan selalu update informasi terbaru terbukti dengan dibuatkan wastafel di depan rumah setiap pemilik homestay dalam rangka protokoler kesehatan dalam menghadapi pandemi covid-19. Kinerja tour operator di desa wisata sumberbulu belum bisa memberikan dukungan terhadap ekonomi lokal karena belum dikelola dengan baik dan kurangnya sumber daya manusia dalam mengelolanya.

\section{REFERENSI}

Darsono. (2005). Pengertian Desa. Diunduh tanggal 10 Maret 2014 dari: http://desasentonorejo.wordpress.com/b ab-ii/

Erna Wigati. (2019). Peran Pemberdayaan Masyarakat Dalam Mengembangkan
Desa Wisata di Desa Sumberbulu Mojogedang Karanganyar. Hotelier Journal Hospitality and Tourism Journal, 44-58

Hadiwijoyo, S.S (2012). Perencanaan Pariwisata Pedesaan Berbasis Masyarakat (Sebuah Pendekatan Konsep). Yogyakarta: Grha Ilmu.

Kemenpar. (2011). Pedoman Kelompok Sadar Wisata. Jakarta: Kementrian Pariwisata dan Ekonomi Kreatif.

Kemenpar. (2019). Buku Panduan Pengembangan Desa Wisata Berbasis Pendampingan Melalui Perguruan tinggi. Jakarta: Asdep Pengembangan SDM dan hubungan Antar lembaga, Deputi Bidang Pengembangan Industri dan Kelembagaan.

Mathew, M.B \& Huberman, M. (1992). Analisis Data Kualitatif Buku Sumber tentang Metode-metode Baru. Jakarta: UIP.

Nuryanti, W. (1993). Desa Wisata. Concept, Perspective and Challenge. Yogyakarta : Gadjah Mada University Press.

Priasukmana, S \& Mulyadin, R.M. (2001). Pembangunan Desa Wisata : Pelaksanaan Undang-undang Otonomi Daerah. Info Sosial Ekonomi.

Sharpley, R. (2009). Tourism, Development and the Environment: Beyond Sustainability? London: Earthscan.

Sugiama, A.G. (2014). Pengembangan Bisnis dan Pemasaran Aset Pariwisata. Bandung: Guardaya Intimarta.

Sugiama, A.G. (2016). Manajemen Aset Pariwisata. Bandung: Guardaya Intimarta. 
Weaver, D \& Oppermann, M (2000). Tourism Manajement. John wiley \& sons: Australia.

World Tourism Organization. (2011). Indicators of Sustainable Develoment fir Tourism Destinations.

\section{BIODATA PENULIS}

\section{Erna Wigati, S.Pd.,M.Pd}

Akademi Pariwisata Mandala Bhakti

Surakarta, Indonesia.

Email: ernawigati16@gmail.com

Bidang Kajian Pariwisata, Perhotelan dan

Pendidikan

Penggerak Pariwisata Indonesia

Khususnya Desa Wisata

Trainer SDM Desa Wisata

Narasumber CHSE

Id Scholar: bNaZ4VcAAAAJ 